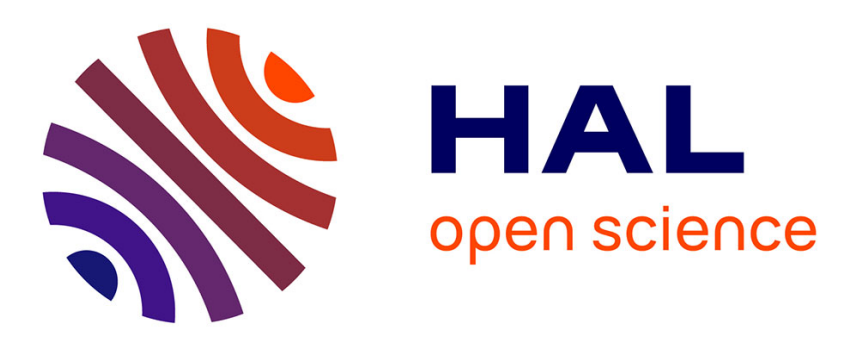

\title{
Allometric models to estimate the aboveground biomass of tropical highlands savannahs trees.
}

Baudoin Junior Wouokoue Taffo, Théophile Fonkou, Victor François Nguetsop

\section{To cite this version:}

Baudoin Junior Wouokoue Taffo, Théophile Fonkou, Victor François Nguetsop. Allometric models to estimate the aboveground biomass of tropical highlands savannahs trees.. Cameroon Journal of Experimental Biology, 2018, 12, 12 (1), pp.49-56. hal-02045394

\section{HAL Id: hal-02045394 https://hal.science/hal-02045394}

Submitted on 8 Mar 2019

HAL is a multi-disciplinary open access archive for the deposit and dissemination of scientific research documents, whether they are published or not. The documents may come from teaching and research institutions in France or abroad, or from public or private research centers.
L'archive ouverte pluridisciplinaire $\mathbf{H A L}$, est destinée au dépôt et à la diffusion de documents scientifiques de niveau recherche, publiés ou non, émanant des établissements d'enseignement et de recherche français ou étrangers, des laboratoires publics ou privés. 


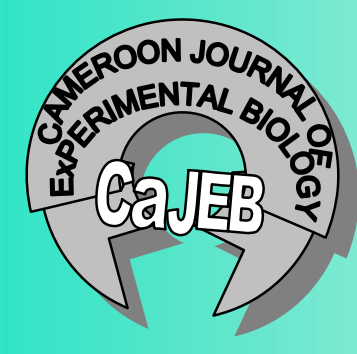

ISSN 1816-0573

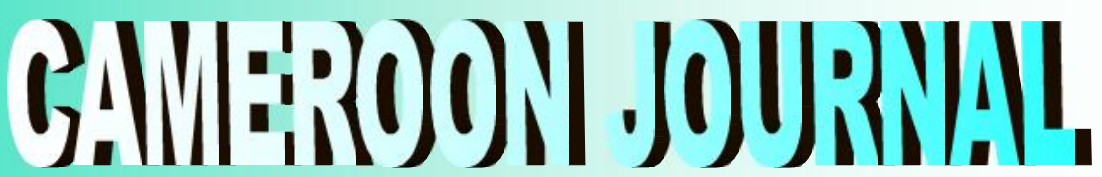

1):'

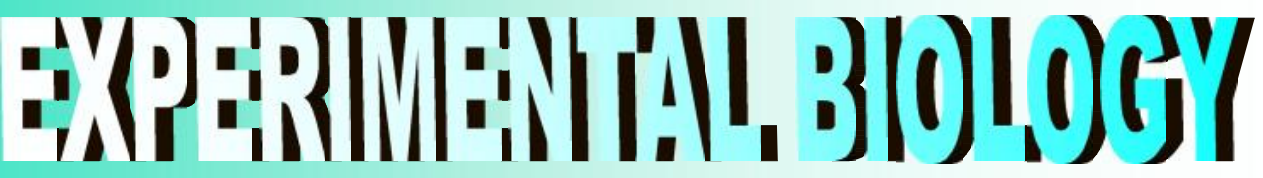

Volume 12, Number 01, June 2018

A Publication of the Cameroon Forum for Biological Sciences

CAFOBIOS 


\section{CONTENTS}

\section{Animal biology}

\section{Original articles}

TRAORE Bakari, HIEN OLLO Chérubin, DIARRA Boureima, NIKIEMA Alain Désiré, BOUGOUMA/YAMEOGO Valérie Marie Christiane et BELEM Andrien A. M. G. Caractéristiques morpho biométriques des populations de lapin (Oryctolagus cuniculus) au Burkina Faso. Page $01-10$.

WEKERE Christian, KINGHA TEKOMBO Bernice Mireille, DONGOCK NGUEMO Delphine, DJAKBE DAPSIA Jackson, FAÏBAWA Esaie et TCHUENGUEM FOHOUO Fernand-Nestor. Exploitation des fleurs de Ageratum conyzoides, Sida rhombifolia et Stylosanthes guianensis par Apis mellifera (Hymenoptera: Apidae) à Dang (Ngaoundéré, Cameroun). Page 11 $-21$.

TCHUENGUEM FOHOUO Fernand-Nestor, DJAKBE DAPSIA Jackson, NGAKOU Albert, WEKERE Christian, LOUABE Stéphane \& FAÏBAWA Esaie Impact de l'activité de butinage de Apis mellifera Linné (Hymenoptera: Apidae) sur la pollinisation et les rendements de Ceratotheca sesamoides Endl. (Pedaliaceae) à Dang (Ngaoundéré, Cameroun). Page 22 -31 .

\section{Pharmacology}

\section{Original articles}

TINDANO Basile, BAYALA Balé1, GUENNE Samson, DOUKOURE Maya, KIENDREBEOGO Martin, BELEMTOUGRI G. Raymond. Innocuity and antioxidant activities of Pentadesma butyracea (1824) leaves for its use in hormone replacement therapy. Page $32-40$.

ATSAMO Albert Donatien, KEUGONG WADO Eglantine, NGUELEFACK-MBUYO Elvine, WATCHO Pierre, NGUELEFACK Télesphore Benoît. Acute and sub-chronic oral toxicity assessment of the leaf aqueous extract of Kalanchoe crenata (Crassulaceae). Page $41-48$.

\section{Plant biology}

\section{Original articles}

WOUOKOUE TAFFO Junior Baudoin, FONKOU Théophile, NGUETSOP Victor François. Allometric models to estimate the aboveground biomass of tropical highlands savannahs trees. Page $49-56$.

TSETAGHO Gabriel Nicodème, FONKOU Théophile, NGUETSOP Victor François, LEKEUFACK Martin. Potentiel fourrager d'Echinochloa crus-pavonis (Kunth) Schult utilisée en phytoépuration des eaux usées domestiques. Page $57-64$.

KOM Meliphe Francis, NGUETSOP Victor François, BREMOND Laurent, FONKOU Théophile, NOUMSI Bernadette, SEBAG David, OSLISLY Richard, TSALEFAC Maurice. Evolution paléohydrologique du marais Paurosa au centre du Gabon au cours des deux derniers millénaires : Contribution des diatomées. Page $65-78$. 


\title{
Allometric models to estimate the aboveground biomass of tropical highlands savannahs trees
}

\author{
WOUOKOUE TAFFO Junior Baudoin, FONKOU Théophile, NGUETSOP Victor François* \\ Laboratory of applied biology, Department of plant biology, Faculty of Sciences, University of Dschang, P.O Box. 67 \\ Dschang, Cameroon. PO. Box 67 Dschang, Cameroon. \\ ${ }^{*}$ Corresponding author E-mail address: vfnguetsop@yahoo.fr
}

\begin{abstract}
The development of tree allometric equations is crucial to accurate savannah carbon assessment. In Africa, the absence of multi-species allometric equations for savannah ecosystems has led to broad use of pan moist tropical equations develop for forest to estimate tree biomass. The aim of this study was to develop accurate multi-species allometric regressions for estimation the aboveground biomass of trees in the Western Highlands savannahs of Cameroon. Data of aboveground woody biomass were obtained from destructive sampling of 103 trees belonging to 7 species across a range of diameter $(5-38 \mathrm{~cm})$. The dry aboveground biomass varied from $6.19 \mathrm{~kg}$ for the smallest tree to $669.45 \mathrm{~kg}$ for the largest tree. Proportional relationships between aboveground biomass and diameter breast height (DBH) are constructed derived from eight regression models (linear, growth, compound, exponential, quadratic, cubic, power and logarithmic). The best models were selected using coefficients of determination $\left(R^{2}\right)$ and relative error. The best local multi-species models using only diameter as input variable were quadratic and cubic regressions with respectively $R^{2}$ of 0.914 and 0.917 . The quadratic model overestimates the biomass with a bias of $0.04 \%$ while the cubic model underestimates it with a $0.012 \%$ bias. In this study, the two multi-species allometric equation developed for savannahs can be used to produce accurate estimates of biomass and carbon stocks from diameter measurement in forest inventory data.
\end{abstract}

Key words: Aboveground biomass, Allometric equations, DBH, Highlands, savannahs.

\section{RÉSUMÉ}

Le développement des équations allométriques des arbres est crucial pour une évaluation précise du carbone de la savane. En Afrique, l'absence des équations allométriques multi-espèces pour les écosystèmes de la savane a conduit à une large utilisation des équations pour estimer la biomasse des arbres des forêts tropicales humides. L'objectif de cette étude était de développer des régressions allométriques multi-espèces précises pour estimer la biomasse aérienne des arbres dans les savanes des Hautes Terres de l'Ouest Cameroun. Les données de la biomasse aérienne des ligneux ont été obtenues à partir des échantillons destructifs de 103 arbres appartenant à 7 espèces dans une gamme de diamètre (5$38 \mathrm{~cm}$ ). La biomasse aérienne variait de $6,19 \mathrm{~kg}$ pour le plus petit arbre à $669,45 \mathrm{~kg}$ pour le plus grand arbre. Les relations proportionnelles entre la biomasse aérienne et le diamètre à hauteur de poitrine (DHP) ont été construites à partir de huit modèles de régression (linéaire, croissance, composé, exponentiel, quadratique, cubique, puissance et logarithmique). Les meilleurs modèles ont été sélectionnés en utilisant les coefficients de détermination $\left(R^{2}\right)$ et l'erreur relative. Les meilleurs modèles locaux multi-espèces utilisant uniquement le diamètre comme variable d'entrée étaient des régressions quadratiques et cubiques avec respectivement un $\mathrm{R}^{2}$ de 0,914 et 0,917 . Le modèle quadratique surestime la biomasse avec un biais de $0,04 \%$ alors que le modèle cubique la sous-estime avec un biais de $0,012 \%$. Dans cette étude, les deux équations allométriques multi-espèces développée pour les savanes peuvent être utilisée pour produire des estimations précises des stocks de biomasse et de carbone à partir de la mesure du diamètre des données d'inventaire forestier.

Mots clés : Biomasse aérienne, DHP, équations allométriques, savanes, Hautes Terres.

\section{INTRODUCTION}

Forest ecosystems exert a large influence on the global carbon cycle through the flux and storage of carbon in plant biomass and quantification of these carbon fluxes and stocks depends to a great degree on allometric models used to estimate aboveground tree biomass [1]. Total aboveground biomass is frequently estimated using allometric models, which express the tree biomass as a function of easily measurable variables such as diameter at breast height, total height and/or wood density [2]. Although many techniques exist for estimating forest biomass at different spatial scales, they all ultimately rely on ground and destructive measurements of individual tree biomass [7]. One of the major sources of uncertainty in estimating the amount of biomass is the lack of reliable regression equations which can 
convert accurately the parameters measured directly in the field into biomass. General and site specific allometric equations have been developed from biomass of mixed tropical species [1]; [8]; [9]; [14]; [4]; [11]; [13]; [10]. However, few allometric equations for biomass estimation have been developed specifically for African tropical savannahs. For biomass estimations in African savannahs, general allometric equations derived from data collected outside Africa are often used [1]; [9]. This pantropical model developed by [1] are largely consider as the best current approximation for the sites for which the local equations are not available. [1] showed that the predictive power of their total models differs between the sites; for some areas, the relative error could be less, whereas for others, it could be high. For this reason, the evaluation of the accuracy of these models with new data and in various geographical places is necessary. At the local scale, the simplest models are based only on the diameter at breast height of tree (DBH) which is the best common predicator of biomass in the allometric models because it is strongly correlated with biomass. In addition, DBH can be easily measured in the field and is always available in forest inventories data ([6]; [12]; [15]). When these models exist, they are the most practical options for the aboveground biomass (AGB) evaluation ([3]; [11]). Although the need is great, few allometric equations are available for the savannah formations. They are due to the highly variability of the trees height [4], anthropic disturbances (agriculture, overgrazing and firewood gathering) and changes of land use at the origin of greenhouse gas emissions. These reasons impose the development of methods in order to quantify, in a reliable way, stocks and carbon flow of savannahs. The aim of this study was to develop allometric models for estimating total aboveground biomass from diameter at breast height for woody savannah species.

\section{MATERIALS AND METHODS}

\section{Study area}

The study was carried out in mounts Bambouto and mount Mbapit located in the Western Highlands of Cameroon between latitude $4^{\circ} 54^{\prime}$ $6^{\circ} 36^{\prime}$ North and longitude $9^{\circ} 18^{\prime}$ - $11^{\circ} 24^{\prime}$ East (Figure 1). The Western Highlands of Cameroon cover a surface area of $31192 \mathrm{~km}^{2}$. The climate is of tropical soudanian type with two main seasons, the rainy season that last from Mid-March to Mid-
November and the dry season from November to March. Nevertheless, this general pattern can be modified according to the altitude of the site. Altitude varies from 1100 to $2400 \mathrm{~m}$ above sea level entailing mean annual rainfall variation from 1500 to $2600 \mathrm{~mm}$ in highest altitudes and 3 to 4 months (November/December-March) dry season. The annual average temperature is around $20{ }^{\circ} \mathrm{C}$. The predominant soils are the andosols, ferralitic soils and ferruginous soils. The vegetation is dominated by Pennisetum purpureum and Imperata cylindrica and ligneous cover is strongly influenced by the anthropogenic activities (agricultural and pasture) ([23];[24]).

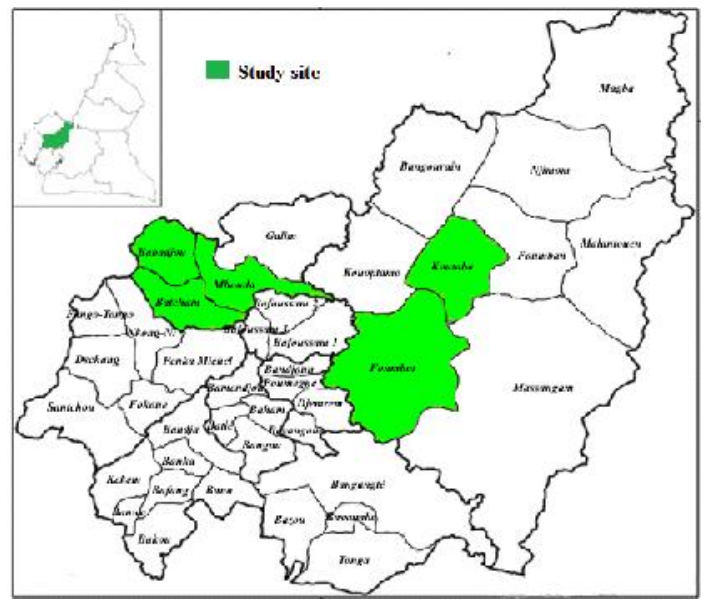

Figure 1. Localization of study site in the West region of Cameroon

\section{Destructive sampling and biomass data}

A total of 103 samples trees with $\mathrm{DBH} \geq 5 \mathrm{~cm}$ belonging to species Terminalia glaucescens Planch. ex Benth (17 individuals), Vitellaria paradoxa C.F.Gaertn (20 individuals), Ficus vallischoudae Delile (16 individuals), Entada africana Guill. \& Perr. (17 individuals), Cussonia arborea Hochst.ex A. Rich (17 individuals), Adenocarpus mannii (Hook. f.) HooK.F (13 individuals) and Erica mannii (HooK.F) Beentje (3 individuals) were harvested for biomass estimation and allometric equation parameterization of the study area. The samples were collected from June to October 2015. Tree species selection was based on their distribution in the different diameter classes and their abundance. We excluded trees with $\mathrm{DBH}<5 \mathrm{~cm}$ because such trees hold a small fraction of AGB in woodlands and would otherwise dominate the signal in regression models. The common practice for measuring DBH (diameter at 
breast height) is to measure trunk diameter at 130 $\mathrm{cm}$ aboveground. Each tree was felled at ground level and separated into bole, branches and leaves. For trees with multiple stems, the bole biomass of one single stem was considered as the sum of weights of each stem of this tree. Each section was weighed in the field using a steelyard of $100 \mathrm{~kg}$ capacity. A sample of 2-cm thick disk was cut from the base of each stem section and oven-dried at $105^{\circ} \mathrm{C}$ until constant weight. Moisture content of the sample was subsequently evaluated. The dry mass was measured with an electronic balance (precision=1 g) in the laboratory and was used to estimate the moisture content. The biomass of each bole section was calculated by multiplying the wet mass of each component by the dry/wet ratio of each sample. The total biomass of a tree was calculated by summing the dry mass of the stems, branches and leaves.

\section{Data analysis and modelling}

Allometric model construction was based on regressing a dependent variable (AGB), against independent variable $(\mathrm{DBH})$. We fitted the following model relating $A G B$ to the compound variable using SPSS 20 software: Linear: $Y=a+$ $b X$; Logarithmic : $Y=a+b \ln (X) ;$ Quadratic : $Y=$ $a+b X+c X^{2}$; Cubic: $Y=a+b X+c X^{2}+d X 3$; Compound : $Y=a b X$; Power: $Y=a X b$; Growth: $Y=\exp (a+b X)$; Exponential: $Y=a \mathrm{e}(b X)$ and Polynomial: $Y=a+b X 1+c X^{2}+d X 3 \ldots$ axn+p with $X$ being the $D B H$ and $Y$ being aboveground biomass. Before establishing the allometric equation, scatter plots were used to see whether the relationship between independent and dependent variables was linear (Figure 2).

\section{Evaluation of the quality of allometric selected} models

To select the best statistical model, we used the coefficient of determination $\left(R^{2}\right)$. Besides goodness of fit measures, we evaluate a posteriori the performance of the regression model by measuring the deviation of the predicted versus measured total AGB of study site and was expressed as a relative error as outlined by [1]. Error $=100$ (AGB predict - AGB measured)/AGB measured. The comparison of the means was done by statistical tests of ANOVA and permit to check the distribution around the slope of the regression.

\section{RESULTS \\ Chemical analysis \\ Models of allometric equations developed}

Diameter at breast height varies from $5.3 \mathrm{~cm}$ to $37.04 \mathrm{~cm}$. Total dry aboveground biomass for study site was $6585.01 \mathrm{~kg}$ and varied between $6.19 \mathrm{~kg}$ for the smallest tree and $669.45 \mathrm{~kg}$ for the largest tree. The correlation test between the biomass and $\mathrm{DBH}$ is done through the analysis of the distribution of the scatter dots of these two parameters. Figure 2 shows the distribution of dry biomass as function of diameter and shows that the increase in the diameter of trees did not take the same pattern as that of the corresponding biomass. The variation of biomass increases slowly as function of diameter classes until a certain diameter of trunk $(\approx 21 \mathrm{~cm})$, then increases very quickly afterwards, although the number of samples in this section is relatively low. The variation of these two parameters shows that we do not have a linear relation between the $\mathrm{DBH}$ and biomass. This figure shows thus that the greatest risks of bias are located at the level of trees with large diameter $(>21 \mathrm{~cm})$. We can observe on the cloud of dots a greater dispersion of biomass values of large trees that express a certain irregularity in the relation between the later and DBH. This shows that we can obtain a good prediction of biomass for trees with small diameters $(<21 \mathrm{~cm})$ which are dominant in the savannah ecosystems.

70

$600)$

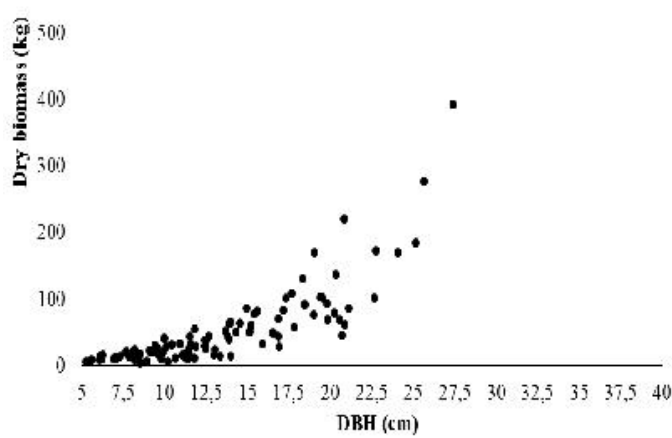

Figure 2. Cloud of dot of the total dry biomass $(\mathrm{kg})$ as function of the diameter at breast height (cm) for 103 trees.

\section{Multi-specific allometric equations developed}

Eight multi-species allometric models related to highlands savannahs were tested with only diameter at breast height (Table 1). The models 
showed very different coefficients of determination $\left(R^{2}\right)$, explaining the differences of models in adjusting of raw data. Thus, to better approximate the biomass from the $\mathrm{DBH}$, the regressions with highest adjusted $\mathrm{R}^{2}(>0.9)$ were retained. Models with highest $\mathrm{R}^{2}$ led to very weak residues. The table 1 shows the results of the adjustment of several allometric models, the quadratic and cubic models respectively have the greatest value of $R^{2}$ (0.914 and 0.917 respectively).

Table 1. Models description based on diameter at breast height for the estimation of total aboveground biomass of highlands savannahs

\begin{tabular}{llcccc}
\hline Model & Regression formula $(\mathbf{y}=)$ & Error $(\%)$ & $\mathbf{R}^{\mathbf{2}}$ & Adj R $^{\mathbf{2}}$ & SEE \\
\hline Linear & $13.944 \times \mathrm{DBH}-128.292$ & 0.002 & 0.679 & 0.676 & 56.504 \\
Exponential & $4.124 \mathrm{e}^{(0.156 \times \mathrm{DBH})}$ & 2.16 & 0.808 & 0.806 & 0.448 \\
Growth & $\exp (1.417+0.156 \times \mathrm{DBH})$ & 2.18 & 0.808 & 0.806 & 0.448 \\
Compound & $4.124 \times 1.169 \mathrm{DBH}$ & 2.515 & 0.808 & 0.806 & 0.448 \\
Power & $0.131 \times \mathrm{DBH}$ & -17.06 & 0.784 & 0.782 & 0.476 \\
Cubic & $37.501-5.284 \mathrm{DBH}+0.234 \mathrm{DBH}^{2}+0.011 \mathrm{DBH}^{3}$ & -0.012 & 0.917 & 0.914 & 29.09 \\
Quadratic & $93.403-16.652 \mathrm{DBH}+0.893 \mathrm{DBH}^{2}$ & 0.04 & 0.914 & 0.912 & 29.439 \\
Logarithmic & $-360.289+166.994 \mathrm{In}(\mathrm{DBH})$ & -0.048 & 0.473 & 0.468 & 72.363 \\
\hline
\end{tabular}

$\mathrm{Y}$ - aboveground biomass, DBH - diameter at breast height, SEE - standard error of estimate, Adj $\mathrm{R}^{2}$ - adjusted value of the coefficient of determination

These adjusted models explain more than $90 \%$ of variability in the biomass. These coefficients of determination indicate a strong relation between the biomass and $\mathrm{DBH}$.

Using only diameter in the allometric equation predicted total aboveground biomass of the savannah with more accuracy and better goodness of fit of data (Figure 3 and 4).

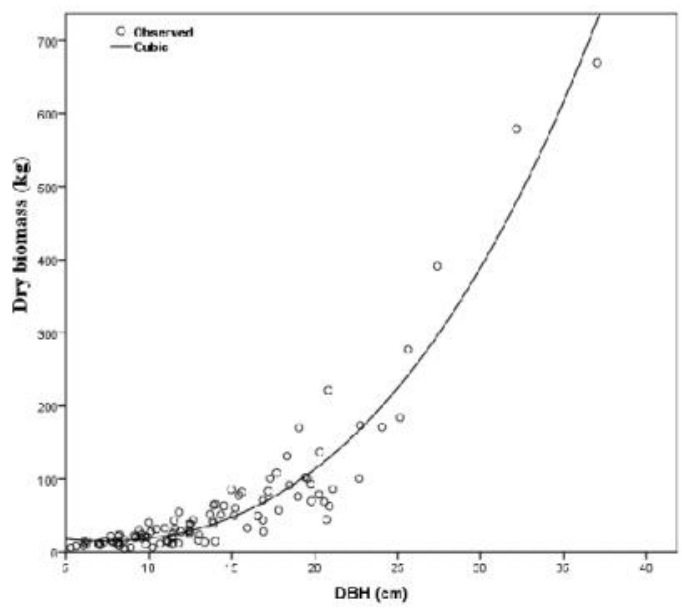

Figure 3. Relationship between aboveground biomass (AGB) and tree diameter (D). Each dot corresponds to an individually weighed tree. Black line corresponds to the curve of predictions of biomass by cubic regression models.

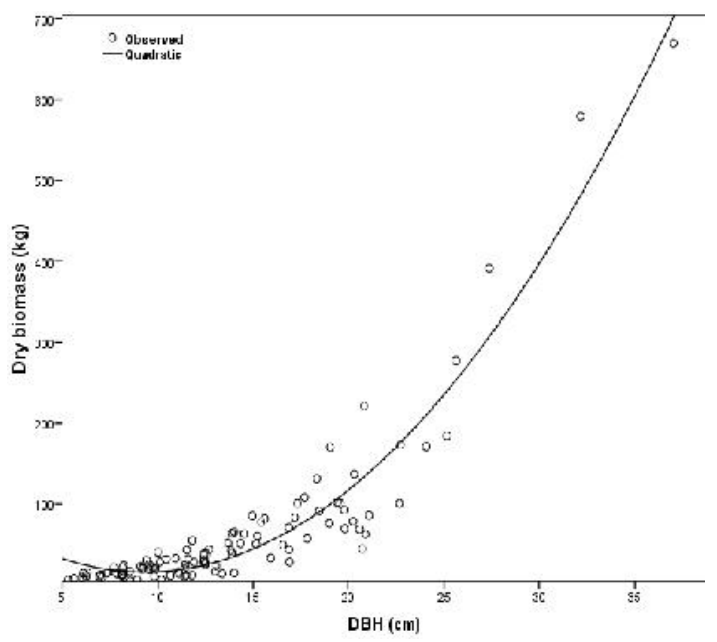

Figure 4. Relationship between aboveground biomass (AGB) and tree diameter (D). Each dot corresponds to an individually weighed tree. Black line corresponds to the curve of predictions of biomass by quadratic regression models.

\section{Accuracy of biomass estimation}

A very strong allometric relationship between aboveground biomass and diameter at breast height for the compiled trees was obtained. Such relationship implied that the variability of aboveground biomass could be highly explained by the variability of diameter at breast height at a global scale since the datasets originate from Highlands savannas and for species belonging to different genera and families. To test the 
consistency of fits, we compared the values directly measured in the field through destructive methods for all trees (103) with estimations of our models. The result confirms simple model (cubic and quadratic) to be of the best estimating aboveground biomass from DBH in the study site. These two models have indeed shown low relative errors and high coefficients of determination; respectively $0.012 \%$ and adjusted $\mathrm{R}^{2}>0.914$ for cubic and $0.04 \%$ bias, adjusted $R^{2}>0.912$ for quadratic regression. The analysis of average errors (Table 1) shows that the quadratic and cubic equations are the best estimator. For allometric equations, the errors in the estimates of aboveground biomass from tree diameter were well distributed across the whole range of diameter. The pattern of the graph (Figure 5) is typical of a variance increases with increasing of trees diameter. The calculated value of $F$ is greater than the critical value of $F$, the main hypothesis is rejected and the risk of error is known. The results of the ANOVA statistical tests show that the best models are quadratic and cubic with low $F$ values, reflecting the small differences between the values predicted by these models and the observed data in the field.

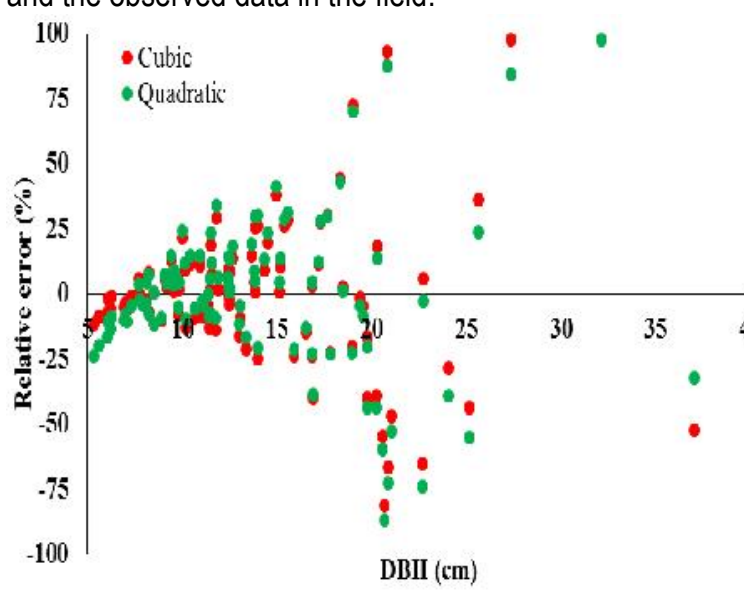

Figure 5. Relationships between the relative error in the estimation of aboveground biomass and tree diameter at breast height. Each dot corresponds to the error made on an individually weighed tree.

\section{Comparison between quadratic and cubic regressions}

We observed that for the smallest diameters (5-9 $\mathrm{cm})$ the best models tend to overestimate trees aboveground biomass. For the average diameters $(9-33 \mathrm{~cm})$ the models underestimate the trees aboveground biomass slightly and for the high diameters greater than $33 \mathrm{~cm}$, they overestimate the trees aboveground biomass (Figure 6).

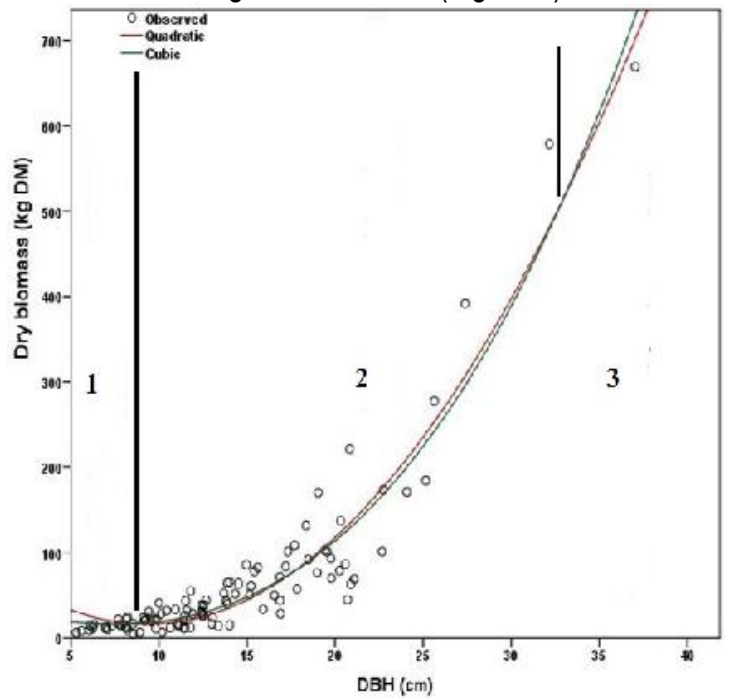

Figure 6. Difference in the best regression models in diameter classes. Each dot corresponds to an individually weighed tree. Red and green lines correspond to quadratic and cubic allometric models respectively.

1 quadratic and cubic models overestimate trees biomass for diameters less than $9 \mathrm{~cm}$

2 quadratic and cubic models underestimate trees biomass for diameters in between $9-33 \mathrm{~cm}$

3 quadratic and cubic models overestimate trees biomass for diameters greater than $33 \mathrm{~cm}$

\section{DISCUSSION}

Concerning the relative contribution of the trees size, it was noted that the small diameter trees can give a significant cover rate, but their impact on the total biomass is less significant than the large trees. However, the presence of young trees implies an active dynamic of sequestration and high potential of growth whereas the old trees reached their limit of growth thus have a low capacity of carbon sequestration. The consequence of low productivity of the savanna ecosystems is the relatively weak sequestration of carbon compared to the tropical forest ecosystems, however they require a careful estimation of carbon for the potential advantages of clean development mechanism projects. Several equations have been published relating tree biomass to diameter or diameter coupled with height. Almost all of these relationships, whether intended for application to particular species, mixed-composition forests, specific sites, 
biogeographical regions, or climate-related biomes, are based on allometric equations [22]. The study of [21] with 132 trees in Central Amazon showed that simple model with only diameter as input is a good estimator which estimates biomass of mixed-species only with an average error of $19.8 \%$. Using only diameter as input variable, the mixed-species regression model (cubic, and quadratic) provided a satisfactory estimation of biomass with an average error of only 0.012 and $0.04 \%$ respectively. The test of mixed-species allometric equations shows that variation in aboveground biomass was explained at more than $90 \%$ just only by diameter for best models. These results indicate that $\mathrm{DBH}$ is a strong indicator of aboveground biomass, which implies that the variability of trees biomass in the savannah ecosystems is largely explained by the variability of $\mathrm{DBH}$. The apparently small differences in the equations for small trees could add up to a large amount of carbon when looking at a landscape; this is an example of bias problem. In this study, the mixed-species allometric equations using diameter at breast height predicted total aboveground biomass of the stand with more accuracy and better goodness of data fit. Similar to our findings, [4] indicated in the allometric equations related to the tree species of sudanian and sudano-guinean savannahs of Senegal that, the variation in biomass was explained by diameter at breast height. Diameter at breast height is the common and best predictor for biomass in allometric models because it is strongly correlated with biomass; in addition, $\mathrm{DBH}$ can be easily measured in the field and is always available in forest inventories data ([5]; [20] ). These results agree with previous reports ([3]; [6]; [9]) that diameter alone is a good predictor of biomass especially in terms of the multiple tradeoffs between accuracy, cost and practicability of measurements. The value of model constants varies with species, stand age, site quality, climatic conditions and stocking of stands constraints in the aboveground biomass variation. In the presence of complex environmental gradients, allometric equations can provide additional information to improve the knowledge of biomass distribution ([1]; [18]). [19] reported that, the variation in environmental factors such as topography and edaphic characteristics (e.g. soil nutrient availability) may complicate attempts to generalize aboveground biomass on a regional or landscape scale.
On the mathematical logic plan, the quadratic model is a very simple function compared with the cubic model, but the later express better the logic of tree growth. Indeed, the trunk of a tree increases in volume and follows a cubic logic. This logic is related to a growth of cylinder surface of the bole but also a vertical growth explaining cubic logic. Both models are the most adapted due to the fact that they present less bias for the large diameters and predict well the small diameters. It has, however, been shown that allometric models that focus on large trees tend overestimate biomass for small trees ([16]; [17]).

\section{CONCLUSION}

The present study showed that the multi-species regression equations developed for the Western Highlands savannahs provide good estimates of total aboveground biomass of when using only diameter as input variable. They can be used to improve estimations of total aboveground biomass from diameter measurements in vegetation inventory data. These findings are especially timely given the urgent need to quantify biomass and carbon stocks in the tropics. The best allometric equations to quantify the aboveground biomass of the savannah from the diameter at breast height are the cubic and quadratic regressions. These models explained more than $90 \%$ of the variability of the total aboveground biomass. Regression models should not be used beyond their range of validity. The models proposed here are valid in the range $5-38 \mathrm{~cm}$ for diameter and the resulting AGB estimated from the equation is then in kilograms. These will improve the quality of tropical biomass estimates and bring consensus regarding the contribution of the savannah to the global carbon cycle.

\section{ACKNOWLEDGMENTS}

The authors thank IDEA WILD that donated some equipment for the field data collection.

\section{REFERENCES}

1. Chave J., Andalo C., Brown S., Cairns M.A., Chambers J.Q., Eamus D., Folster H., Fromard F., Higuchi N., Kira T., Lescure J.P., Nelson B.W., Ogawa $H_{\text {., }}$ Puig $H_{\text {., Riera }}$. and Yamakura T. 2005. Tree allometry and improved estimation of carbon stocks and balance in tropical forests. Oecologia 145(1): 87-99. 
2. Parresol B.R. 1999. Assessing tree and stand biomass: a review with examples and critical comparisons. Forest Science 45(4): 573-593

3. Basuki T.M., van Laake P.E., Skidmore A.K. and Hussin Y.A. 2009. Allometric Equations for Estimating the Aboveground Biomass in Tropical Lowland Dipterocarp Forests. Forest Ecology and Management 257(8): 1684-1694.

4. Mbow C. 2009. Potentiel et dynamique des stocks de carbone des savanes soudaniennes et soudano-guinéennes du Sénégal. Thèse de Doctorat d'état en sciences, Université Cheikh Anta Diop de Dakar, $386 \mathrm{p}$

5. Zianis D. and Mencuccini M. 2003. Aboveground biomass relationships for beech (Fagus moesiaca Cz.) trees in Vermio Mountain, northern Greece, and generalised equations for Fagus sp. Annals of Forest Science 60: 439448.

6. Zianis D. and Mencuccini M. 2004. On simplifying allometric analyses of forest biomass. Forest Ecology and Management 187: 311-332.

7. Gibbs H.K., Brown S., Niles J.O. and Foley J.A. 2007. Monitoring and estimating tropical forest carbon stocks: making REDD a reality. Environmental Research Letters 2(4): 1-13.

8. Djomo A.N., Adamou I., Joachim S. and Gode G. 2010. Allometric equations for biomass estimations in Cameroon and pan moist tropical equations including biomass data from Africa. Forest Ecology and Management 260(10): 1873-1885.

9. Brown S., Gillespie A.J.R. and Lugo A.E. 1989. Biomass estimation methods for tropical forests with application to forest inventory. Forest Science 35(4): 881-902.

10. Brown S. 1997. Estimating biomass and biomass change of tropical forests: a primer UN FAO Forestry Paper 134, Rome, pp 55. http://www.fao.org/docrep/W4095E/W4095E00. htm

11. Sierra C.A., del Valle J.I., Orrego S.A., Moreno F.H., Harmon M.E., Zapata M., Colorado G.J., Herrera M.A., Lara W., Restrepo D.E., Berrouet L.M., Loaiza L.M. and Benjumea J.F. 2007. Total carbon stocks in a tropical forest landscape of the Porce region, Colombia. Forest Ecology and Management 243: 299-309.

12. Yen T.M., Ji Y.J. and Lee J.S. 2010. Estimating biomass production and carbon storage for a fast-growing makino bamboo (Phyllostachys makinoi) plant based on the diameter distribution model. Forest Ecology and Management 260: 339-344.

13. Ketterings Q.M., Coe R., Van Noordwijk M., Ambagau Y. and Palm C.A. 2001. Reducing uncertainty in the use of allometric biomass equations for predicting above-ground tree biomass in mixed secondary forests. Forest Ecology and Management 146: 199-209.

14. Henry M., Besnard A., Asante W.A., Eshun J., AduBredu S., Valentini R., Bernoux M. and Saint-André L. 2010. Wood density, phytomass variations within and among trees and allometric equations in a tropical rainforest of Africa. Forest Ecology and Management 260(8): 1375-1388.

15. Shackleton C.M. and Scholes R.J. 2011. Above ground woody community attributes, biomass and carbon stocks along a rainfall gradient in the savannas of the central lowveld, South Africa. South African Journal of Botany 77: 184-192.

16. Van Breugel M., Ransijn J., Craven D., Bongers F. and Hall J.S. 2011. Estimating carbon stock in secondary forests: decisions and uncertainties associated with allometric biomass models. Forest Ecology and Management 262(8): 1648-1657.

17. Deans J.D., Moran J. and Grace J. 1996. Biomass relationships for tree species in regenerating semi-deciduous tropical moist forest in Cameroon. Forest Ecology and Management 88(3): 215-225.

18. Alvarez E., Duque A., Saldarriaga J., Cabrera K., Salas G.D.L., Valle L.D., Lema A., Moreno F., Orrego S. and Rodriguez L. 2012. Tree above-ground biomass allometries for carbon stocks estimation in the natural forests of Colombia. Forest Ecology and Management 267: 297-308.

19. Mani S. and Parthasarathy N. 2007. Aboveground biomass estimation in ten tropical dry evergreen forest sites of peninsular India. Biomass and Bioenergy 31: 284-290.

20. Rebeiro C.S., Fehrmann L., Boechat S.C.P., Gonçalves J.L.A., Kleinn C. and de Oliveira Gaspar R. 2011. Above- and belowground biomass in a Brazilian Cerrado. Forest Ecology and Management 262: 491-499.

21. Nelson B.W., Mesquita R., Pereira J.L.G., de Souza S.G.A., Batista G.T. and Couta L.B., 1999. Allometric regressions for improved estimate of secondary forest biomass in the 
Central Amazon. Forest Ecology Management 117: 149-167.

22. Cole T.G. and Ewel J.J. 2006. Allometric equations for four valuable tropical tree species. Forest Ecology Management 229: 351-360

23. Wouokoue T. J. B., Nguetsop V. F., Fonkou T., 2017. Floristic diversity of Western Highlands savannas of Cameroon. International Journal of
Current Research in Biosciences and Plant Biology 4(4): 7-13

24. Wouokoue T. J. B., Anjah G. M., Nguetsop V. F., Fonkou T., 2017. Floristic diversity of the savannah ecosystems in three altitudinal zones of Bambouto Mountains, West Cameroon. Cameroon Journal of Biological and Biochemical Sciences $25:$ : 52-59 